\title{
Hepatic regeneration in fulminant hepatic failure
}

\author{
GERALD Y MINUK, MD, FRCPC
}

\begin{abstract}
GY MINUK. Hepatic regeneration in fulminant hepatic failure. Can J Gastroenterol 1993;7(7):545-546. Survival in patients with fulminant hepatic failure (FHF) depends on whether regenerative activity is prompt enough and of sufficient magnitude to restore hepatic function to necessary levels prior to the development of life threatening complications. Unfortunately, in the setting of FHF, the liver's ability to regenerate is impaired, both in terms of the rapidity of its onset and magnitude. The reason(s) for this impairment remain unclear and are the subject of extensive investigations. Data from studies in experimental animals and early reports in humans with acute liver failure suggest that there is no deficiency and, in fact, there is an excess of many hepatic growth promoters. Thus, either an intrinsic defect exists in the remnant liver's ability to respond to these growth promoters or growth inhibitors are present to an even greater extent. The results of previous cross-circulation experiments and documentation of extremely high concentrations of newly identified growth inhibitors suggest that the latter are more likely to be operative. As a result, therapeutic endeavours are targeted at lowering the levels of various growth inhibitors. An exciting new approach - based on the realization that many of these growth inhibitors act through a common final pathway - has been to exogenously administer the product of this pathway in an attempt to optimize regenerative activity in FHF.
\end{abstract}

Key Words: Fulminant hepatic failure, Hepatic regeneration, Hyperplasia, Hypertrophy

\section{Régénération hépatique dans l'insuffisance hépatique fulminante}

RÉSUMÉ: La survie chez les patients atteints d'insuffisance hépatique fulminante dépend de la rapidité de l'activité régénératrice et de l'amplitude du retour d'une fonction hépatique suffisante avant le développement des complications fatales. Malheureusement, dans le contexte de l'insuffisance hépatique fulminante, la capacité du foie à se régénérer est altérée, tant en terme de rapidité qu'en terme d'amplitude. On comprend mal encore ce phénomène et il fait présentement l'objet d'études à grande échelle. Les données tirées des études expérimentales menées chez l'animal et les rapports préliminaires d'études menées chez des sujets humains en insuffisance hépatique aiguë, suggèrent qu'il n'y aurait pas déficit, mais plutôt excès de certains modulateurs de la croissance hépatique. C'est donc qu'il y a un défaut intrinsèque dans la capacité du foie restant à répondre à ces modulateurs de croissance ou qu'il y a des inhibiteurs de croissance en excès. Les résultats d'expériences précédentes de circulation croisée et la documentation portant sur des concentrations extrêmement élevées d'inhibiteurs de croissance nouvellement identifiés suggèrent que la dernière hypothèse soit la plus probable. Par conséquent, la recherche sur la thérapeutique doit viser un abaissement des taux des divers inhibiteurs de croissance. Une nouvelle approche intéressante, qui se base sur le fait que plusieurs de ces inhibiteurs de croissance agissent par le biais d'une voie terminale commune, a été d'administrer le produit de cette voie pour tenter d'optimiser l'activité régénératrice dans l'insuffisance hépatique fulminante.

Liver Disease Unit, Health Sciences Centre, Winnipeg, Manitoba

Correspondence and reprints: Dr G Minuk, Head, Liver disease Unit, Health Sciences Centre, 820 Sherbrook Street, Winnipeg, Manitoba R3A IR9. Telephone (204) 787-4662, Fax (204) $787-4826$ $\coprod \begin{aligned} & \text { EPATIC REGENERATION IS A VERY } \\ & \text { rapid process. In rats, restitution }\end{aligned}$ of liver mass following a $70 \%$ partial hepatectomy is complete within seven days of the procedure. In humans undergoing large hepatic resections for benign tumours or trauma, the process may take one month unless the liver contains hepatitis or is cirrhotic, in which case three to six months and six to 12 months, respectively, may be required.

Hepatic regeneration actually consists of two processes: hypertrophy and hyperplasia. Hypertrophy represents an increase in liver size due to an accumulation of lipid within hepatocytes. This is a cortisol-dependent process that usually is complete with 6 to $12 \mathrm{~h}$ of initiation of regeneration. Hyperplasia represents an increase in liver size due to an increase in cell number which, in turn, reflects increased DNA synthesis. Although hyperplasia is thought to follow hypertrophy (in the rat, peak DNA synthesis rates occur at $24 \mathrm{~h}$ following partial hepatectomy and $48 \mathrm{~h}$ following chemical-induced hepatitis), the application of new techniques indicates that hyperplasia actually begins much earlier, with an increase in the expression of the early response genes (C-fos, Cmyc and ( $-j u n)$ being detected within 15 to 30 mins of a partial hepatectomy in rats.

What initiates hepatic regeneration is unknown. One possibility is that resting hepatocytes are exposed to excess concentrations of growth promoters (the most potent of which is hepatocyte growth factor, although a dozen others have also been described), relative to growth inhibitors (which include interleukins, transforming growth 
factor-beta (TGF- $\beta$ ), ammonia and gamma-aminobutyric acid (GABA). A second possibility is that the metabolic demand placed on surviving hepatocytes initiates cell entry into the cell cycle $\left(\mathrm{G}_{\mathrm{o}}\right.$ to $\left.\mathrm{G}_{1}\right)$ and, ultimately, DNA synthesis. The precise metabolic demands responsible for this activity have yet to be identified. Once in the cell cycle, continued hepatocyte replication is maintained by the production of yet-to-be-defined autocrine and paracrine growth factors. It is important to note that although many growth promoters have been described in the medical literature, only three have been documented to be essential to the regenerative process: insulin, thyroxin and putrescine.

\section{REGENERATION IN FHF}

Four important questions that remain to be resolved in this area include: is hepatic regeneration impaired in fulminant hepatic failure (FHF)? if so, why? what can be done to stimulate hepatic regeneration? and, what tests are available to monitor hepatic regenerative activity?

To determine whether haptic regeneration is impaired in FHF, one must first document the maximal capacity of the liver to regenerate. Such data can be obtained by performing a $90 \%$ partial hepatectomy in rats and comparing DNA synthesis rates following the procedure to DNA synthesis rates observed in FHF. Such comparisons were recently made in the author's laboratory and the findings indicate that DNA synthesis rates in galactosamineand dimethylnitrosamine-induced FHF rats are less than $50 \%$ that of partial hepatectomized rats.

There are a number of possible explanations for impaired hepatic regeneration in FHF. First, the concentration of growth promoters in the circulation may be inadequate to maximize regenerative activity. While possible, this seems unlikely, given that the concentrations of most growth promoters reported are markedly elevated in FHF. Moreover, the values are not substantially different from those reported fol- lowing a 70 to $90 \%$ partial hepatectomy. A second possibility is that there is an increase in the concentration of circulating growth inhibitors. Although data on TGF- $\beta$ levels and/or mRNA expression are not yet available, interleukins (IL) (particularly IL1), ammonia and GABA concentrations are all significantly elevated in FHF. A third possible explanation is that there is a deficiency in one of the three compounds that are essential for hepatic regeneration in FHF. This is unlikely to apply to insulin and thyroxin levels because the concentrations of these compounds are consistently elevated in animals and patients with FHF. However, recent data from the author's laboratory indicate that hepatic putrescine levels are only $30 \%$ of those required for maximal regenerative activity.

From the above, one might consider enhancing hepatic regeneration in FHF by providing more growth promoters, lowering growth inhibitor levels or replenishing the factor(s) that are essential for hepatic regeneration. It is anticipated that the recent success in cloning and sequencing human hepatocyte growth factor will lead to clinical trials that will determine if exogenous growth promoter therapy is effective in FHF. Although many compounds inhibit interleukin production, no specific inhibitors are yet available. Whether the recently described IL-1 receptor antagonists might play a role in enhancing hepatic regeneration in FHF remains to be determined. Fortunately, techniques and agents capable of lowering plasma ammonia and GABA concentrations are available, and their use should be encouraged in patients with FHF. Finally, Japanese investigators have recently demonstrated that replenishment of hepatic putrescine stores will enhance hepatic regeneration and improve survival rates in galactosamine-induced FHF in rats.

There are no tests presently available which accurately reflect hepatic regeneration in patients with FHF. Serum alpha fetoprotein levels have been purported by some investigators to serve this purpose, but others have not found them useful. Moreover, there is a significant delay (approximately five days) before alpha fetoprotein levels increase in surviving FHF patients with presumed hepatic regenerative activity. A more sensitive test that increases more rapidly and correlates with hepatic regeneration in humans is serum ornithine decarboxylase (ODC) enzyme determinations. ODC is the principal enzyme responsible for putrescine synthesis in the liver. Studies to determine whether ODC activity might serve as a useful marker of hepatic regeneration in FHF are underway.

\section{CONCLUSIONS}

In summary, hepatic regeneration is impaired in FHF. This impairment appears to result from increased levels of circulating growth inhibitors and perhaps a deficiency in compound(s) that are essential for the regenerative process. Until safe and effective forms of therapy become available to enhance hepatic regeneration, efforts should be made to limit the increases in plasma ammonia and GABA concentrations with aggressive anti-encephalopathic measures (bowel evacuation, neomycin, lactulose, etc). Noninvasive tests are not available to document hepatic regenerative activity in patients with FHF. This is an area that researchers must address, particularly if new therapeutic agents are to be subjected to controlled clinical trials.

\section{SUGGESTED READING}

1. Gove CD, Hughes RD. Liver regeneration in relationship to acute liver failure. Gut 1991;(Suppl):592-6.

2. Hughes RD, Yamada H, Gove LD, Williams. Inhibitors of hepatic DNA synthesis in fulminant hepatic failure. Dig Dis Sci 1991;36:816-9.

3. Leffert HL, Koch KS, Lad PJ, Skelly H, deHemptinne B. Hepatocyte regeneration, replication, and differentiation. The Liver: Biology and Pathobiology. New York: Raven Press, 1982:601-14.

4. Michalopoulos GK. Liver regeneration: Molecular mechanisms of growth control. FASEB J 1990;4:176-87.

5. Tsubouchi H, Hirono S, Gohda E, et al. Clinical significance of human hepatocyte growth factor in blood from patients with fulminant hepatic failure. Hepatology 1989;9:875-81. 


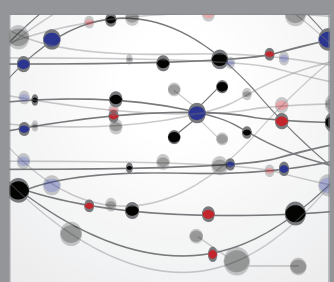

The Scientific World Journal
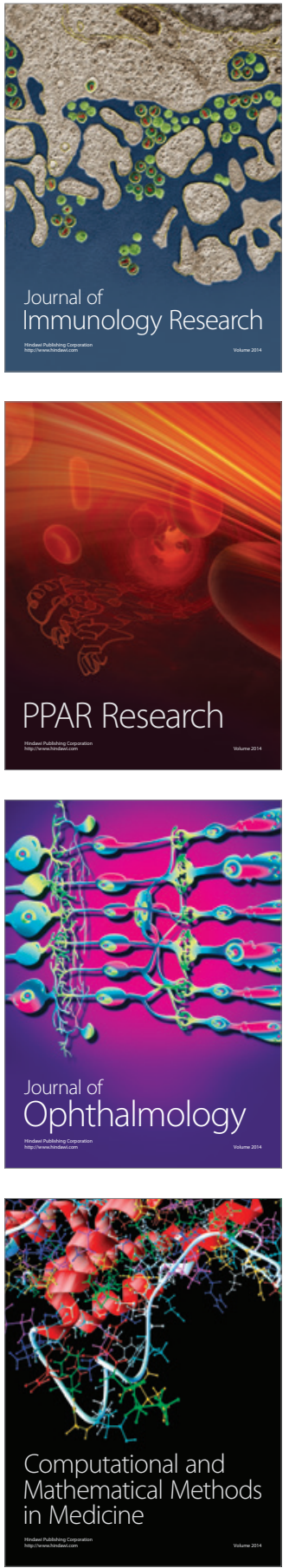

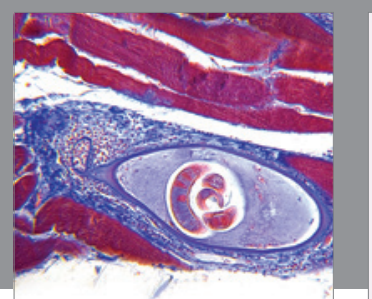

Gastroenterology Research and Practice

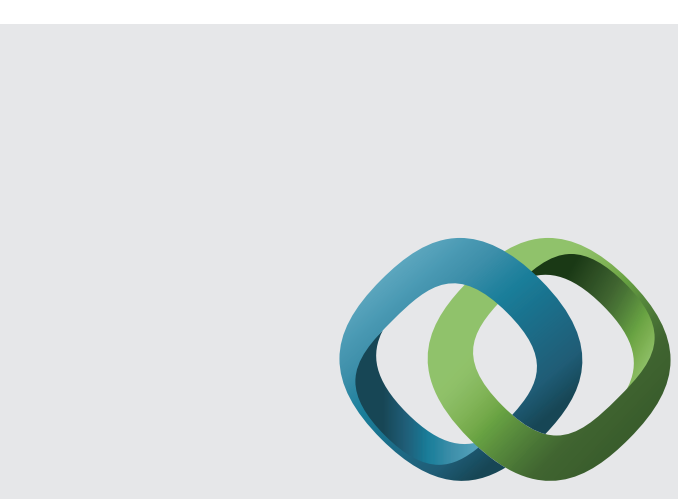

\section{Hindawi}

Submit your manuscripts at

http://www.hindawi.com
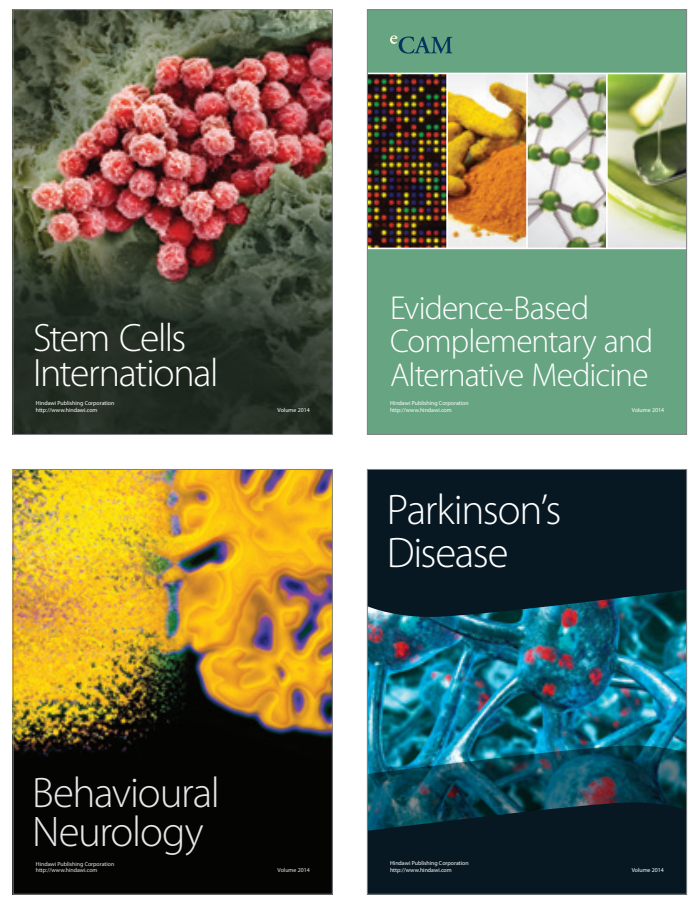
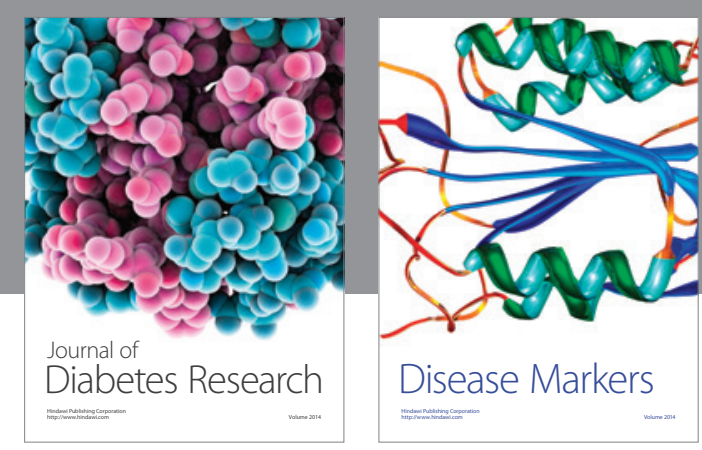

Disease Markers
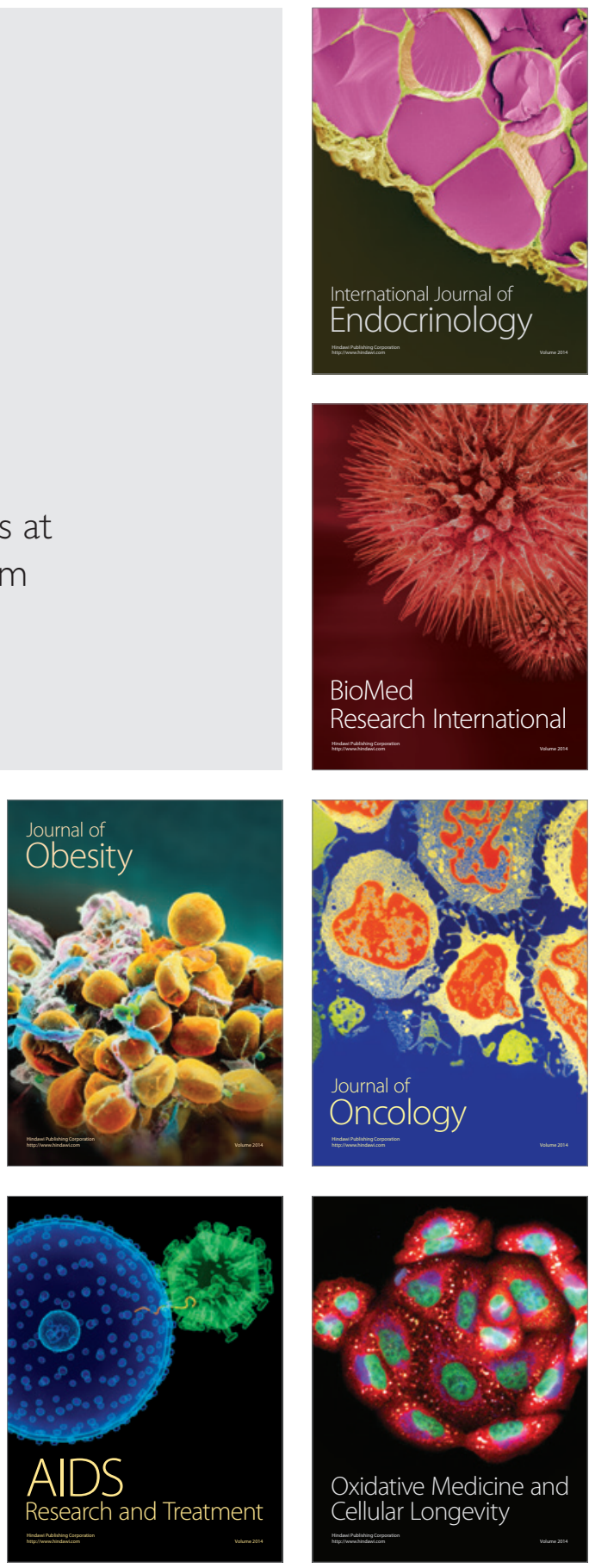